\title{
Identification of Acetobacter, Gluconobacter, and Asaia Strains Isolated in Thailand Based on 16S-23S rRNA Gene Internal Transcribed Spacer Restriction and 16S rRNA Gene Sequence Analyses
}

\author{
SOMbOOn TANASUPAWAT ${ }^{*}$, Jintana KOMMANEE ${ }^{1}$, TAWEESAK MALIMAS ${ }^{2}$, PATTARAPORn YUKPHAN $^{2}$, \\ YASUYOSHI NAKAGAWA ${ }^{3}$, and YUZO YAMADA ${ }^{2,4,5}$ \\ ${ }^{1}$ Department of Microbiology, Faculty of Pharmaceutical Sciences, Chulalongkorn University, 254 Phayathai Road, \\ Wangmai, Bangkok 10330, Thailand; ' 2 BIOTEC Culture Collection (BCC), National Center for Genetic Engineering and \\ Biotechnology (BIOTEC), 113 Thailand Science Park, Phaholyothin Road, Klong 1, Klong Luang, Pathumthani 12120, \\ Thailand; ${ }^{3}$ Biological Resource Center (NBRC), Department of Biotechnology, National Institute of Technology and \\ Evaluation (NITE), 2-5-8, Kazusakamatari, Kisarazu Chiba 292-0818, Japan; ${ }^{4}$ Japan International Cooperation Agency \\ (JICA Senior Overseas Volunteer), 2-1-1 Yoyogi, Shibuya-ku, Tokyo 151-8558, Japan; and ${ }^{5}$ Shizuoka University \\ (Professor Emeritus), 836 Ohya, Suruga-ku, Shizuoka 422-8529, Japan
}

(Received December 7, 2008—Accepted March 8, 2009—Published online April 10, 2009)

Twenty-six strains of acetic acid bacteria were isolated from fruits, flowers and related materials collected in Thailand. They were divided into three genera, Acetobacter, Gluconobacter and Asaia, by phenotypic characterization and $16 \mathrm{~S}$ rRNA gene sequence analyses. On the basis of 16S-23S rRNA gene internal transcribed spacer (16S-23S rDNA ITS) restriction and 16S rRNA gene sequence analyses, fourteen isolates assigned to the genus Acetobacter were divided into five groups: 1) Group 1A or A. tropicalis (one isolate); 2) Group 2A or A. orientalis (four isolates); 3) Group 3A or A. pasteurianus (five isolates); 4) Group 4A or A. syzygii (one isolate); and 5) Group 5A or A. ghanensis (three isolates). The eleven isolates assigned to the genus Gluconobacter were divided into three groups: 6) Group 1B or G. frateurii (four isolates); 7) Group 2B or G. japonicus (six isolates); and 8) Group 3B or unidentified (one isolate). The remaining isolate was placed into: 9) Group 1C or unidentified, which was assigned to the genus Asaia and considered to constitute a new species on the basis of the 16S rRNA gene sequence analysis and DNA-DNA hybridization.

Key words: Acetic acid bacteria, Acetobacter, Asaia, Gluconobacter, 16S-23S rDNA ITS restriction analyses

Acetic acid bacteria (AAB) are Gram-negative, aerobic, rod-shaped bacteria assigned to the Alphaproteobacteria. These bacteria have undergone considerable changes, consequently increasing the number of novel genera and species. Presently, there are a total of 11 genera (Euzéby, 2008, URL: http://www.bacterio.net): Acetobacter, Gluconobacter, Acidomonas, Gluconacetobacter, Asaia, Kozakia, Swaminathania, Saccharibacter, Neoasaia, Granulibacter, and Tanticharoenia $(7,10,12,13,18,19,25,28,33,38,39$, 42-45). These bacterial strains have been isolated from fruits, flowers, vinegar, grapes, wine, sake, cider, beer, soft drink, nata, sugarcane, bee hives, tea fungus, plant materials and so on (13).

Many new acetic acid bacteria have been reported in Thailand, including the genera Neoasaia and Tanticharoenia, and the species Asaia krungthepensis, Gluconobacter albidus, Gluconobacter thailandicus, Neoasaia chiangmaiensis, Gluconobacter kondonii, Gluconobacter roseus, Asaia lannaensis, Tanticharoenia sakaeratensis, and Gluconobacter japonicus (11, 21-24, 31, 39, 40, 42-45). In addition, Acetobacter pasteurianus, Gluconacetobacter liquefaciens, Asaia bogorensis, Asaia siamensis, Acetobacter orientalis, Acetobacter lovaniensis, Gluconobacte frateurii (15, 20, 27, 41, 44), and all seven groups of Gluconobacter except Gluconobacter

\footnotetext{
* Corresponding author. E-mail: Somboon.T@chula.ac.th; Tel: +662-2188376; Fax: +662-2188376.
}

cerinus (9) isolated from fruits, flowers and other materials collected in Thailand have been found. In the course of isolating, identifying and classifying acetic acid bacteria in Thailand, we have continued the taxonomic study of Thai isolates based on 16S-23S rRNA gene internal transcribed spacer (16S-23S rDNA ITS) restriction and 16S rRNA gene sequence analyses as well as phenotypic characterization and DNA-DNA hybridization. This paper is concerned with the identification of novel isolates from fruits, flowers, and other materials.

\section{Materials and Methods \\ Isolation of acetic acid bacteria and reference strains}

Thirteen fruits, two other materials collected at markets and two kinds of flowers that fell from trees were cut into small pieces and enriched using a glucose/ethanol/yeast extract (GEY) medium. An isolation source was incubated at $\mathrm{pH} 4.5$ and $30^{\circ} \mathrm{C}$ for $3-5$ days in a liquid medium $\left(15 \mathrm{~mL}\right.$ tube $^{-1}$ ) composed of $2.0 \%$ D-glucose, $5.0 \%$ ethanol and $1.0 \%$ yeast extract (all by w/v). When microbial growth was seen, the culture was streaked onto a GEY-agar plate containing $0.3 \% \mathrm{CaCO}_{3}(\mathrm{w} / \mathrm{v})(36)$. Acetic acid bacteria were selected as acid-producing bacterial strains, which formed clear zones around colonies on the agar plate. A. indonesiensis NBRC $16471^{\mathrm{T}}$, A. cibinongensis NBRC $16605^{\mathrm{T}}$, A. lovaniensis NBRC $13753^{\mathrm{T}}$, A. tropicalis NBRC $16470^{\mathrm{T}}$, A. orientalis NBRC $16606^{\mathrm{T}}$, A. pasteurianus TISTR $1056^{\mathrm{T}}$, A. aceti NBRC $14818^{\mathrm{T}}$, A. syzygii NBRC $16604^{\mathrm{T}}$, A. ghanensis LMG 23848, G. frateurii NBRC $3264^{\mathrm{T}}$, G. thailandicus BCC $14116^{\mathrm{T}}$, G. japonicus NBRC $3271^{\mathrm{T}}$, G. 
cerinus NBRC $3267^{\mathrm{T}}$, G. oxydans NBRC $14819^{\mathrm{T}}$, G. albidus NBRC $3250^{\mathrm{T}}$, G. kondonii NBRC 3266 ${ }^{\mathrm{T}}$; Asaia lannaensis BCC $15733^{\mathrm{T}}$, Asaia bogorensis $\mathrm{BCC} 12264^{\mathrm{T}}$, Asaia siamensis $\mathrm{BCC} 12268^{\mathrm{T}}$, and Asaia krungthepensis BCC $12978^{\mathrm{T}}$ were used as reference strains.

\section{Phenotypic characterization}

Phenotypic characterization was carried out by incubating isolates at $30^{\circ} \mathrm{C}$ and $\mathrm{pH} 6.8$ for two days on glucose/yeast extract/ peptone/glycerol (GYPG) agar, which was composed of $1.0 \%$ Dglucose, $1.0 \%$ glycerol, $0.5 \%$ yeast extract, $1.0 \%$ peptone, and $1.5 \%$ agar (all by w/v), unless otherwise mentioned. For the Gram staining of bacterial cells, the Hucker-Conn modified method was used (8). Physiological and biochemical characterizations were made by the methods of Asai et al. (1), Gosselé et al. (6), and Yamada et al. (36). Isolates were grown in GEY medium on a rotary shaker (150 $200 \mathrm{rpm})$ at $30^{\circ} \mathrm{C}$ for $24 \mathrm{~h}$.

\section{Chemotaxonomic characterization}

AAB were grown in GEY broth on a rotary shaker (150-200 $\mathrm{rpm})$ at $30^{\circ} \mathrm{C}$ for $24 \mathrm{~h}$. Ubiquinone was extracted from freeze-dried cells by shaking with a mixture of chloroform-methanol $(2: 1, \mathrm{v} / \mathrm{v})$. Cells were removed by filtration, and the combined filtrates were evaporated dry under reduced pressure on a rotary evaporator. The resulting residue was dissolved in a small volume of acetone, and subjected to thin-layer chromatography on a silica gel plate $\left(20 \times 20 \mathrm{~cm}\right.$, silica gel $60 \mathrm{~F}_{254}$, Art 5715 , E. Merck, Darmstadt, Germany) with a solvent system of pure benzene (35). The purified ubiquinone preparation was subjected to reversed-phase paper chromatography $(35,37)$ and to high performance liquid chromatography (29).

\section{$16 S$ rRNA gene sequence analyses}

The 16S rRNA genes of strains were amplified by PCR with Taq DNA polymerase and primers; 20F (5'-GAGTTTGATCCTGGCTCAG'-3, the Escherichia coli numbering system (2) and 1500R (5'GTTACCTTGTTACGACTT'-3) and sequenced, as described previously $(31,40,43)$. The sequencing was carried out with an ABI PRISM BigDye Terminator v3.1 cycle sequencing kit on an ABI PRISM model 310 Genetic Analyzer (Applied Biosystems, Foster City, CA, USA). The following six primers were used for $16 \mathrm{~S}$ rRNA gene sequencing; 20F, 1500R, 520F (5'-CAGCAG-CCGCGGTAATAC-3', positions 519-536), 520R (5'-GTATTACCGCGGCTGCTG-3', positions 536-519), 920F (5'AAACTCAAATGAATTGACGG-3', positions 907-926), and 920R (5'-CCGTCAATTCAT-TTGAGTTT-3', positions 926-907). Multiple alignments of the 16S rRNA gene sequences determined were performed with the program CLUSTAL X (version 1.83) (32). Gaps and ambiguous bases were eliminated from the calculation. Distance

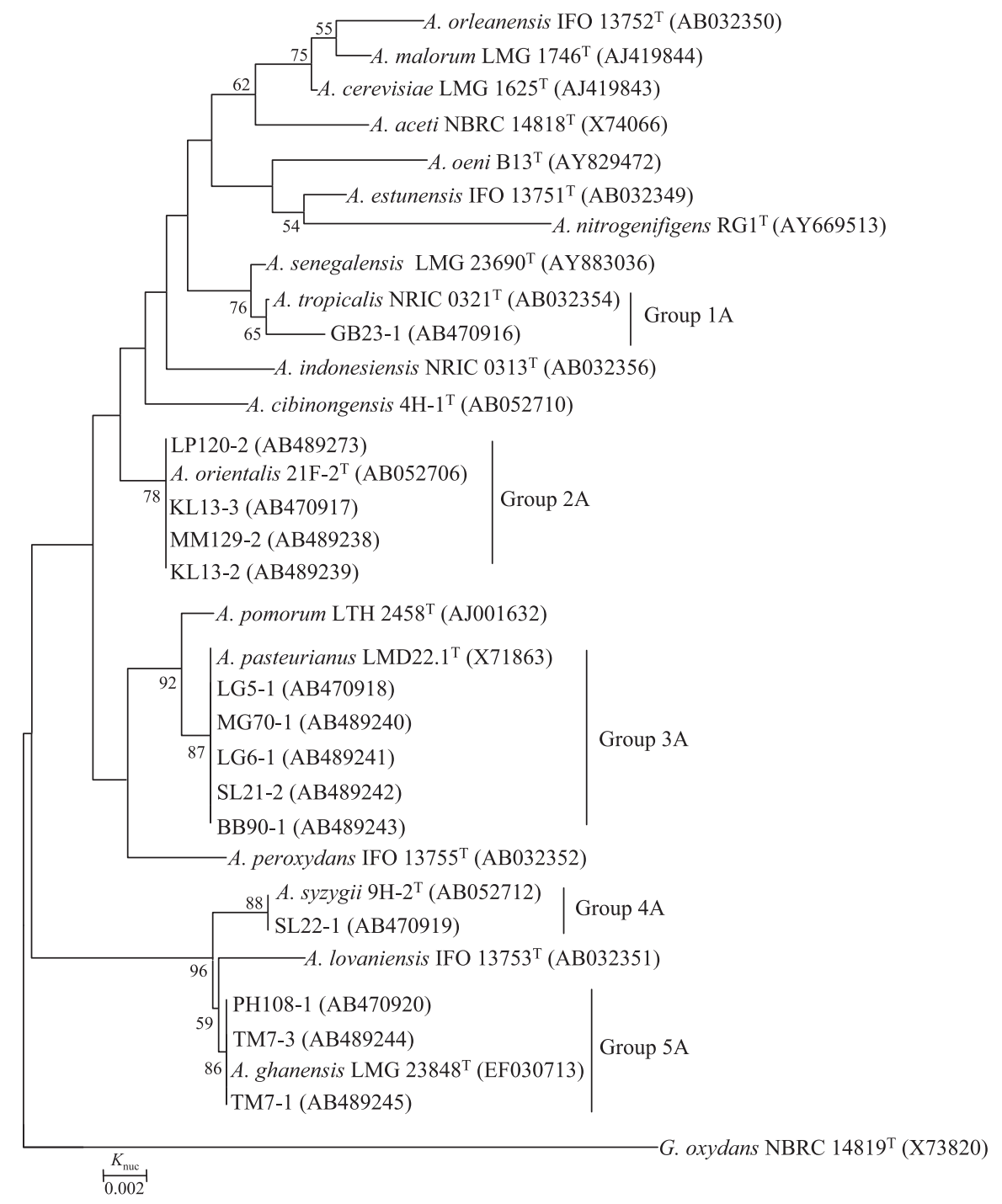

Fig. 1. A phylogenetic tree based on 16S rRNA gene sequences for Thai isolates assigned to the genus Acetobacter. The phylogenetic tree was constructed by the neighbor-joining method. Numerals $(\%)$ at nodes indicate bootstrap values derived from 1,000 replications. 


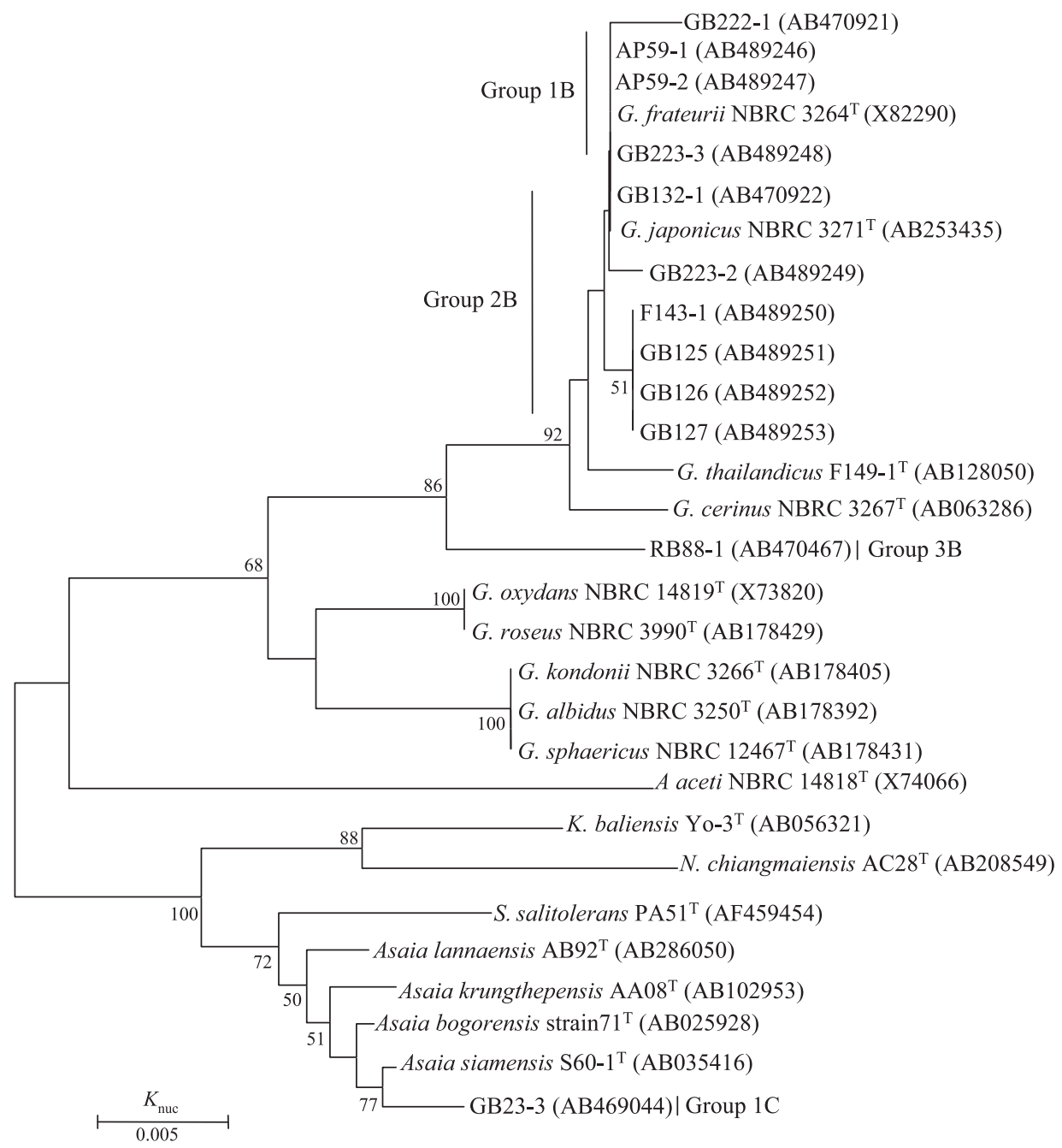

Fig. 2. A phylogenetic tree based on $16 \mathrm{~S}$ rRNA gene sequences for Thai isolates assigned to the genera Gluconobacter and Asaia. The phylogenetic tree was constructed by the neighbor-joining method. Numerals (\%) at nodes indicate bootstrap values derived from 1,000 replications.

matrices for the aligned sequences were calculated by the twoparameter method of Kimura (14). A phylogenetic tree based on $16 \mathrm{~S}$ rRNA gene sequences was constructed by the neighbor-joining method of Saitou and Nei (26) with the program MEGA (version 4.0) (30). The confidence values of individual branches in the phylogenetic tree were determined by using the bootstrap analysis of Felsenstein (5) based on 1,000 replications. Pair-wise 16S rRNA gene sequence similarities were calculated between phylogenetically related strains $(1,381-1,476$ bases of isolates GB23-1, KL133, LG5-1, SL22-1, PH108-1, GB222-1, GB132-1, RB88-1, and GB23-3, and 692-804 bases of the remaining isolates).

\section{Restriction analysis of $16 \mathrm{~S}$-23S rDNA ITS}

The purified PCR products were separately digested with restriction endonucleases; HpaII and HaeIII (New England BioLabs, Beverly, MA, USA) (15) in case of the Acetobacter strains, and MboII (Fermentas, Hanover, MD, USA), Bsp1286I (New England BioLabs), TaqI (Fermentas) and Bst NI (Fermentas) $(20,41)$ in the case of Gluconobacter strains. The resulting reaction products were analyzed by $2.5 \%(\mathrm{w} / \mathrm{v})$ agarose gel electrophoresis developed at $100 \mathrm{~V}$ for $40 \mathrm{~min}$ in $1 \times$ Tris-acetate running buffer.

\section{DNA-DNA hybridization}

Bacterial DNAs were prepared, as described previously (31) DNA-DNA hybridization was carried out by the photobiotin-labeling method using microplate wells (4). Levels of DNA-DNA hybridization were determined colorimetrically (34). The color intensity was measured at $\mathrm{A}_{450}$ on a model VersaMax microplate reader (Molecular Devices, Sunnyvale, CA, USA).

\section{Nucleotide sequence accession numbers}

The 16S rRNA gene sequences for the twenty-six strains in this study have been deposited in DDBJ under the accession numbers AB470916 to AB470920, and AB489237 to AB489245 for Acetobacter strains; AB470467, AB470921, AB470922, and AB489246 to AB489253 for Gluconobacter strains; and AB469044 for the Asaia strain as indicated in the dendogram (Figs. 1 and 2).

\section{Results and Discussion}

The twenty-six Thai isolates were Gram-negative and aerobic rods, produced catalase but not oxidase, and showed clear zones on $\mathrm{GEY} / \mathrm{CaCO}_{3}$ agar plates and growth at $\mathrm{pH}$ 3.5. Fourteen of the isolates were assigned to the genus Acetobacter, since acetate and lactate were intensely oxidized to $\mathrm{CO}_{2}$ and $\mathrm{H}_{2} \mathrm{O}$, and Q-9 was recognized as a major quinone (39) (Table 1). Eleven isolates were assigned to the genus Gluconobacter, since acetate and lactate were not oxidized and Q-10 was recognized as a major quinone (39). One isolate was assigned to the genus Asaia, since the isolate grew on $30 \%$ D-glucose, showed weak oxidation of acetate and lactate, and had Q-10 as a major quinine (39). In addition, the 
Table 1. Characteristics differentiating Thai isolates assigned to the genera Acetobacter, Gluconobacter, and Asaia

\begin{tabular}{|c|c|c|c|c|c|c|c|c|c|c|c|c|c|c|c|c|c|c|c|c|}
\hline Characteristic & 1 & 2 & 3 & 4 & 5 & 6 & 7 & 8 & 9 & 10 & 11 & 12 & 13 & 14 & 15 & 16 & 17 & 18 & 19 & 20 \\
\hline \multicolumn{21}{|l|}{ Oxidation of } \\
\hline Acetate & + & + & + & + & + & + & + & + & + & + & - & - & - & - & - & $\mathrm{W}$ & $\mathrm{w}$ & $\mathrm{w}$ & $\mathrm{W}$ & w \\
\hline Lactate & + & + & + & + & + & + & + & + & + & + & - & - & - & - & - & $\mathrm{W}$ & $\mathrm{w}$ & $\mathrm{w}$ & $\mathrm{w}$ & $\mathrm{w}$ \\
\hline \multicolumn{21}{|l|}{ Acetic acid from ethanol } \\
\hline on ethanol/ $/ \mathrm{CaCO}_{3}$ agar & + & + & + & + & + & + & + & + & + & + & + & + & + & + & + & + & - & - & - & w \\
\hline \multicolumn{21}{|l|}{ Growth on } \\
\hline Glutamate agar & - & - & - & - & - & - & - & - & - & - & - & - & - & - & - & + & + & + & + & + \\
\hline Mannitol agar & - & $\mathrm{w}$ & - & $\mathrm{w}$ & - & $\mathrm{w}$ & $\mathrm{w}$ & $\mathrm{w}$ & $\mathrm{w}$ & $\mathrm{w}$ & + & + & + & + & + & + & + & + & + & + \\
\hline Growth at $37^{\circ} \mathrm{C}$ & + & + & + & + & + & + & + & + & + & + & + & $+(\mathrm{w} 2)$ & + & + & + & + & + & + & + & + \\
\hline Growth at $40^{\circ} \mathrm{C}$ & - & $\mathrm{w}$ & - & $\mathrm{w}$ & + & + & + & + & - & w & - & - & - & $-(\mathrm{w} 1)$ & $\mathrm{w}$ & - & - & - & - & w \\
\hline \multicolumn{21}{|l|}{ Production of } \\
\hline 2-Keto-D-gluconate & + & + & + & + & - & - & - & - & - & - & + & + & + & + & + & + & + & + & + & + \\
\hline 5-Keto-D-gluconate & - & - & - & - & - & - & - & - & - & - & + & + & + & + & + & + & + & + & + & + \\
\hline \multicolumn{21}{|l|}{ Acid production from } \\
\hline meso-Erythritol & - & - & - & - & + & + & - & - & - & - & $\mathrm{W}$ & $\mathrm{W}$ & + & $\mathrm{W}$ & - & + & + & + & + & $\mathrm{w}$ \\
\hline Maltose & W & - & - & - & - & - & + & + & - & $-(\mathrm{w} 1)$ & $\mathrm{W}$ & $\mathrm{w}(-2)$ & - & - & - & - & - & - & $\mathrm{w}$ & $\mathrm{w}$ \\
\hline Raffinose & $\mathrm{w}$ & - & - & $\mathrm{w}(-2)$ & $\mathrm{w}$ & $\mathrm{w}(-2)$ & - & - & - & - & - & - & $\mathrm{w}$ & $\mathrm{w}(-1)$ & - & $\mathrm{w}$ & + & + & $\mathrm{w}$ & w \\
\hline \multicolumn{21}{|l|}{ Growth on } \\
\hline meso-Erythritol & - & - & - & - & + & + & $\mathrm{w}$ & $\mathrm{W}$ & - & - & - & - & + & + & $\mathrm{w}$ & + & + & + & + & w \\
\hline D-Arabitol & - & - & - & - & - & - & - & - & - & - & + & + & + & + & $\mathrm{w}$ & $\mathrm{w}$ & + & + & + & w \\
\hline L-Arabitol & - & - & - & - & - & - & - & - & - & - & + & + & W & $\mathrm{w}$ & w & $\mathrm{W}$ & + & + & + & w \\
\hline meso-Ribitol & - & - & - & - & - & - & - & - & - & $-(w 1)$ & + & + & + & + & + & + & + & + & + & + \\
\hline
\end{tabular}

Strain:1, A. tropicalis NBRC 16470 ; 2, Group 1A (1 isolate); 3, A. orientalis NBRC 16606 ${ }^{\mathrm{T}}$; 4, Group 2A (4 isolates); 5, A. pasteurianus TISTR $1056^{\mathrm{T}}$; 6, Group 3A (5 isolates); 7, A. syzgii NBRC 16604 $;$; 8, Group 4A (1 isolate); 9, A. ghanensis LMG 23848 G. frateurii NBRC 3264 ${ }^{\mathrm{T}}$; 12, Group 1B (4 isolates); 13, G. japonicus NBRC 3271 ${ }^{\mathrm{T}}$; 14 , Group 2B (6 isolates); 15, Group 3B (1 isolate); 16, Asaia lannaensis $\mathrm{BCC} 15733^{\mathrm{T}}$; 17, Asaia bogorensis $\mathrm{BCC} 12264^{\mathrm{T}}$; 18, Asaia siamensis $\mathrm{BCC} 12268^{\mathrm{T}}$; 19, Asaia krungthepensis $\mathrm{BCC} 12978^{\mathrm{T}}$; 20 , Group 1C (1 isolate); +, positive; w, weakly positive; -, negative. Numbers in parentheses indicate the number of isolates showing a weakly positive or negative reaction.

16S rRNA gene sequence analysis supported that they belong to the genera Acetobacter, Gluconobacter, and Asaia (Figs. 1 and 2).

\section{Isolates assigned to the genus Acetobacter}

The fourteen isolates that were assigned to the genus Acetobacter were divided into five groups, 1A, 2A, 3A, 4A, and $5 \mathrm{~A}$, by the $16 \mathrm{~S}$ rRNA gene sequence analysis (Fig. 1) and 16S-23S rDNA ITS restriction analysis with restriction endonucleases HpaII and HaeIII (Table 2 and Fig. 3).

In a phylogenetic tree based on $16 \mathrm{~S}$ rRNA gene sequences $(1,431 \mathrm{bp})$, the isolate GB23-1 (Group 1A) was located within the cluster of $A$. tropicalis (Fig. 1) and showed 99.8\% pair-wise $16 \mathrm{~S}$ rRNA gene sequence similarity with the type strain of A. tropicalis. It also gave restriction patterns that coincided with those of the type strain (Table 2 and Fig. 3). It tested positive for catalase activity, the oxidation of ethanol to acetic acid, and the oxidation of acetate and lactate to carbon dioxide and water. D-Gluconate and 2-keto-D-gluconate were produced from D-glucose. The isolate tested negative for oxidase activity and ketogenesis from glycerol. It produced acids from L-arabinose, D-galactose, D-glucose, and Dmannose, and to less of an extent, from maltose, raffinose, and D-xylose, but not at all from D-arabinose, dulcitol, mesoerythritol, D-fructose, glycerol, lactose, D-mannitol, D-melibiose, L-rhamnose, L-sorbose, D-sorbitol, and sucrose. It did not grow on meso-erythritol, D-arabitol, L-arabitol or mesoribitol. It showed almost the same phenotypic characteristics as $A$. tropicalis NBRC $16470^{\mathrm{T}}$ (Table 1). Therefore, GB23-1 isolated from a flower of Spathodea campanulata was identi- fied as $A$. tropicalis (16).

Isolates of Group 2A included LP120-2, KL13-2, KL13-3, and MM129-2. In a phylogenetic tree based on 16S rRNA gene sequences $(1,381 \mathrm{bp})$, all the isolates were located within the cluster of $A$. orientalis (Fig. 1). Additionally, LP120-2, KL13-2, KL13-3, and MM129-2 had 99.8, 99.6, 99.9 , and $99.5 \%$ pair-wise $16 \mathrm{~S}$ rRNA gene sequence similarity with the type strain of $A$. orientalis, respectively. They also showed restriction patterns that coincided with those of the type strain of $A$. orientalis (Table 2 and Fig. 3). All the isolates of Group 2A produced 2-keto-D-gluconate from Dglucose. They produced acid from D-glucose, and in some cases, from mannose. Some isolates produced acids weakly from L-arabinose, raffinose, and xylose, but none produced acid from D-arabinose, dulcitol, meso-erythritol, D-galactose, D-fructose, glycerol, lactose, maltose, D-mannitol, Dmelibiose, L-rhamnose, L-sorbose, D-sorbitol, or sucrose. The isolates did not grow on meso-erythritol, D-arabitol, L-arabitol and meso-ribitol. They showed almost the same phenotypic characteristics as A. orientalis NBRC $16606^{\mathrm{T}}$ (Table 1). Therefore, the four isolates were identified as $A$. orientalis (17). They were found in fruits of kaffir lime, in musk-melon and in loog-pang khaomak (Table 2).

Isolates of Group 3A included LG5-1, LG6-1, MG70-1, SL21-2, and BB90-1. In a phylogenetic tree based on 16S rRNA gene sequences $(1,460 \mathrm{bp})$, all of the isolates of Group 1A were located within the cluster of A. pasteurianus (Fig. 1). Additionally, LG5-1, LG6-1, MG70-1, SL21-2, and BB90-1 had 99.9\% pair-wise 16S rRNA gene sequence similarity with the type strain of $A$. pasteurianus. They 
Table 2. Identification of Thai isolates based on $16 \mathrm{~S}-23 \mathrm{~S}$ rDNA ITS restriction analysis

\begin{tabular}{|c|c|c|c|c|c|c|c|c|}
\hline \multirow{2}{*}{ Isolate } & \multicolumn{2}{|c|}{ Isolation source } & \multicolumn{6}{|c|}{ Restriction pattern by digestion with } \\
\hline & Source & Province & HpaII & HaeIII & MboII & Bsp1286I & TaqI & $B s t \mathrm{NI}$ \\
\hline GB23-1 & $\begin{array}{l}\text { Spathodea } \\
\text { campanulata }^{1}\end{array}$ & & At & At & & & & \\
\hline LP120-2 & Loog-pang khaomak ${ }^{3}$ & Pathumthani & Ao & $A o, A c, A a$ & & & & \\
\hline KL13-2, KL13-3 & Kaffir lime ${ }^{2}$ & Bangkok & Ao & $A o, A c, A a$ & & & & \\
\hline MM129-2 & Musk-melon ${ }^{2}$ & Bangkok & Ao & $A o, A c, A a$ & & & & \\
\hline LG5-1, LG6-1 & Longan $^{2}$ & Bangkok & $A p$ & $A p, A i, A t$ & & & & \\
\hline MG70-1 & Mango $^{2}$ & Bangkok & $A p$ & $A p, A i, A t$ & & & & \\
\hline SL21-2 & Sapodilla $^{2}$ & Bangkok & $A p$ & $A p, A i, A t$ & & & & \\
\hline BB90-1 & Banana $^{2}$ & Bangkok & $A p$ & $A p, A i, A t$ & & & & \\
\hline SL22-1 & Sapodilla $^{2}$ & Bangkok & As & $A s, A g, A l$ & & & & \\
\hline TM7-1, TM7-3 & Tomato $^{3}$ & Bangkok & $A g$ & $A s, A g, A l$ & & & & \\
\hline PH108-1 & Peach $^{2}$ & Pathumthani & $A g$ & $A s, A g, A l$ & & & & \\
\hline AP59-1, AP59-2 & Apple $^{2}$ & Bangkok & & & $G f, G t, G j$ & $G f, G t, G j$ & $G f, G t, G c, G a, G k$ & $G f, G t$ \\
\hline GB222-1 & Guava $^{2}$ & Bangkok & & & $G f, G t, G j$ & $G f, G t, G j$ & $G f, G t, G c, G a, G k$ & $G f, G t$ \\
\hline GB223-3 & Sugar apple ${ }^{2}$ & Bangkok & & & $G f, G t, G j$ & $G f, G t, G j$ & $G f, G t, G c, G a, G k$ & $G f, G t$ \\
\hline F143-1 & Canna indica ${ }^{1}$ & Bangkok & & & $G f, G t, G j$ & $G f, G t, G j$ & $G j$, Go & $G j$ \\
\hline GB132-1 & Manila tamarind ${ }^{2}$ & Bangkok & & & $G f, G t, G j$ & $G f, G t, G j$ & $G j$, Go & $G j$ \\
\hline $\begin{array}{l}\text { GB125, GB126, } \\
\text { GB127 }\end{array}$ & Plum mango $^{2}$ & Nakhonpathom & & & $G f, G t, G j$ & $G f, G t, G j$ & $G j$, Go & $G j$ \\
\hline GB223-2 & Sugar apple $^{2}$ & Bangkok & & & $G f, G t, G j$ & $G f, G t, G j$ & Gj, Go & $G f, G t, G j$ \\
\hline RB88-1 & Rambutan $^{2}$ & Bangkok & & & $G u$ & $G u$ & Gj, Go & $G u$ \\
\hline GB23-3 & $\begin{array}{l}\text { Spathodea } \\
\text { campanulata }^{1}\end{array}$ & Bangkok & & & - & - & - & - \\
\hline
\end{tabular}

${ }^{1}$ Flower, ${ }^{2}$ Fruit, ${ }^{3}$ Other materials; Aa; A. aceti; Ac, A. cibinongensis; At, A. tropicalis; Ao, A. orientalis; As, A. syzygii; Ap, A. pasterianus; Ag, A. ghanensis; Al, A. lovaniensis; Ai, A. indonesiensis; Go, G. oxydans; Gf, G. frateurii; Gt, G. thailandicus; Gj, G. japonicus; Gu, unidentified; -, not tested.

(a) HpaII

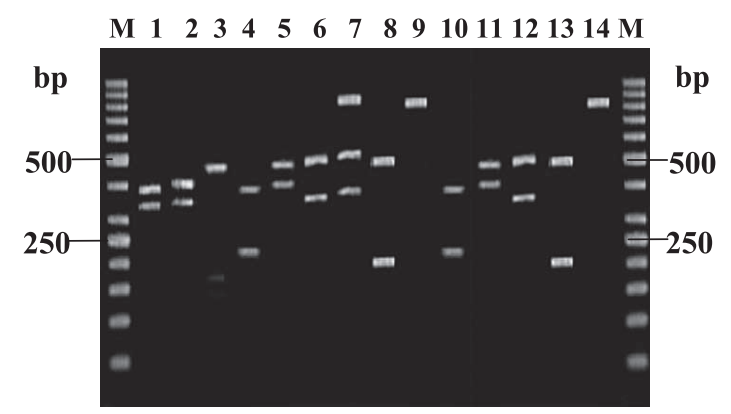

(b) HaeII

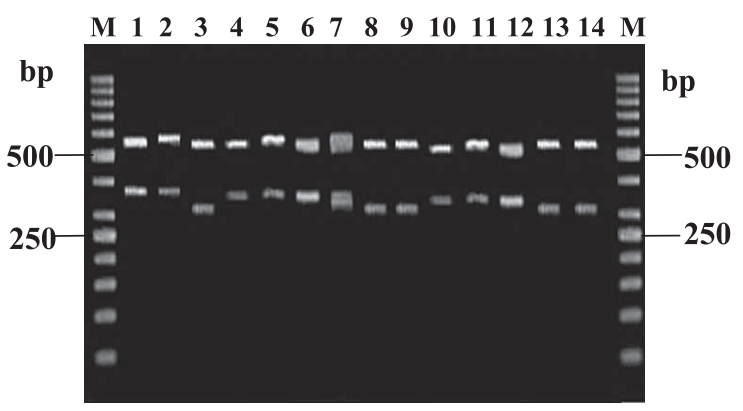

Fig. 3. Restriction of 16S-23S rDNA ITS PCR products of Thai isolates assigned to the genus Acetobacter. The restriction patterns were obtained by digestion of 16S-23S rDNA ITS PCR products with HpaII (a) and HaeIII (b). For the estimation of digestion fragments produced from 16S-23S rDNA ITS PCR products, 50-bp DNA markers were used in the agarose gel electrophoresis. Strain: 1 , A. indonesiensis NBRC $16471^{\mathrm{T}}$; 2 , A. cibinongensis $\mathrm{NBRC} 16605^{\mathrm{T}} ; 3$, A. lovaniensis NBRC $13753^{\mathrm{T}} ; 4$, A. tropicalis $\mathrm{NBRC}_{16470^{\mathrm{T}}} ; 5$, A. orientalis NBRC $16606^{\mathrm{T}} ; 6$, A. pasteurianus TISTR 1056 ; 7, A. aceti NBRC 14818 ${ }^{\mathrm{T}}$; 8, A. syzygii NBRC 16604 $;$; 9, A. ghanensis LMG 23848 ${ }^{\mathrm{T}}$; 10, GB23-1 (Group 1A); 11, KL13-3 (Group 2A); 12, LG5-1 (Group 3A), 13, SL22-1 (Group 4A); 14, PH108-1 (Group 5A).

showed restriction patterns that coincided with those of $A$. pasteurianus TISTR $1056^{\mathrm{T}}$, when digested with $\mathrm{HpaII}$ and HaeIII (Table 2 and Fig. 3). They did not produce 2-keto-Dgluconate from D-glucose. All grew at $40^{\circ} \mathrm{C}$. Acid was produced from L-arabinose, meso-erythritol, D-fructose, D-galactose, D-glucose, D-mannose, D-melibiose, and D-xylose, and weakly from D-arabinose, glycerol, D-sorbitol, and sucrose. Some produced acid weakly from dulcitol and raffinose but none produced acid from lactose, maltose, D-mannitol, Lrhamnose, or L-sorbose. They grew on meso-erythritol, but not on D-arabitol, L-arabitol and meso-ribitol. They showed almost the same phenotypic characteristics as A. pasteurianus TISTR $1056^{\mathrm{T}}$ (Table 1). The five isolates were therefore identified as $A$. pasteurianus (15). The isolates were found in fruits of longan fruit, mango, sapodilla and banana (Table 2).

Group 4A contained only one isolate SL22-1. In a phylogenetic tree based on 16S rRNA gene sequences $(1,412 \mathrm{bp})$, the isolate was located within the cluster of $A$. syzygii (Fig. 1) and showed $99.9 \%$ pair-wise $16 \mathrm{~S}$ rRNA gene sequence simi- 
larity to the type strain of $A$. syzygii. It had restriction patterns that coincided with those of $A$. syzygii NBRC $16604^{\mathrm{T}}$ (Table 2 and Fig. 3). All grew at $40^{\circ} \mathrm{C}$. The isolate produced acids from D-glucose and maltose but not from L-arabinose, D-arabinose, dulcitol, meso-erythritol, D-fructose, D-galactose, glycerol, lactose, maltose, D-mannitol, D-melibiose, Lrhamnose, raffinose, L-sorbose, D-sorbitol, sucrose, and Dxylose. It grew weakly on meso-erythritol, but did not grow on D-arabitol, L-arabitol or meso-ribitol. It showed the same phenotypic characteristics as $A$. syzygii NBRC $16604^{\mathrm{T}}$ (Table $1)$. Therefore, the isolate from sapodilla was identified as $A$. syzygii (17).

Isolates of Group 5A included TM7-1, TM7-3, and PH1081. In a phylogenetic tree based on $16 \mathrm{~S}$ rRNA gene sequences (1,442 bp), all the isolates were located within the cluster of A. ghanensis (Fig. 1). Additionally, TM7-1, TM7-3, and PH108-1 had $99.9 \%$ pair-wise $16 \mathrm{~S}$ rRNA gene sequence similarity with the type strain of $A$. ghanensis. They showed restriction patterns that coincided with those of $A$. ghanensis LMG $23848^{\mathrm{T}}$ (Table 2 and Fig. 3). The isolates produced acid from D-glucose and to a lesser extent, from D-arabinose and D-sorbitol. Some produced acids from L-arabinose, Dfructose, D-mannose, D-melibiose and D-xylose but none did so from meso-erythritol, dulcitol, D-galactose, glycerol, lactose, maltose, D-mannitol, L-rhamnose, raffinose (one weakly), L-sorbose, or sucrose. They did not grow on meso-erythritol, D-arabitol, L-arabitol and meso-ribitol (one weakly). They showed almost the same phenotypic characteristics as A. ghanensis LMG $23848^{\mathrm{T}}$ (Table 1). The three isolates were therefore identified as $A$. ghanensis (3). They were found in fruits of peach and tomato (Table 2).

(a) MboII

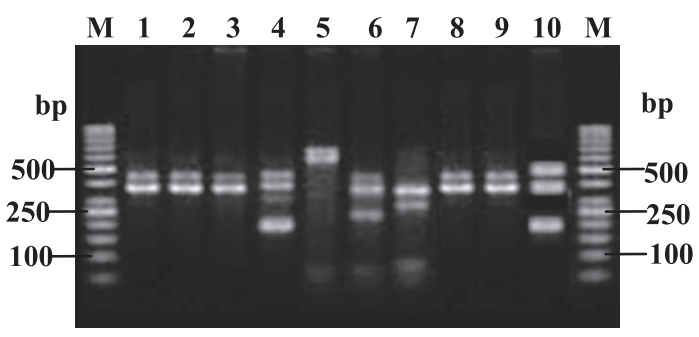

\section{Isolates assigned to the genus Gluconobacter}

The eleven isolates that were assigned to the genus Gluconobacter were divided into three groups, 1B, 2B, and $3 \mathrm{~B}$, by the $16 \mathrm{~S}$ rRNA gene sequence analysis (Fig. 2) and $16 \mathrm{~S}-23 \mathrm{~S}$ rDNA ITS restriction analysis with the endonucleases MboII, Bsp1286I, TaqI, and Bst NI (Table 2 and Fig. 4).

Group 1B was composed of four isolates, GB222-1, GB223-3, AP59-1, and AP59-2. In a phylogenetic tree based on $16 \mathrm{~S}$ rRNA gene sequences $(1,476 \mathrm{bp})$, all the isolates were located within the cluster of $G$. frateurii (Fig. 2). GB222-1, GB223-3, AP59-1, and AP59-2 had 99.7, 99.9, 99.9 , and $99.9 \%$ pair-wise $16 \mathrm{~S}$ rRNA gene sequence similarity with the type strain of $G$. frateurii, respectively. All the isolates gave the same restriction patterns as the type strain of $G$. frateurii (Table 2 and Fig. 4) (20-22, 24, 31, 41). The isolates produced dihydroxyacetone from glycerol and grew at $30^{\circ} \mathrm{C}$. Some did not grow at $37^{\circ} \mathrm{C}$. 2-Keto-D-gluconate and 5-keto-D-gluconate were produced from D-glucose, but not 2,5-diketo-D-gluconate. They produced acids from Larabinose, D-galactose, D-glucose, meso-erythritol (weakly), and D-xylose (weakly), but not from D-arabinose, dulcitol, D-fructose, lactose, D-mannose, D-mannitol, D-melibiose, Lrhamnose, raffinose, L-sorbose, and D-sorbitol. Some produced acids from glycerol, maltose (weakly), and sucrose. The isolates showed growth on D-arabitol, L-arabitol and meso-ribitol (weakly) but not on meso-erythritol, being different from strains of G. oxydans and G. cerinus (31). They showed almost the same phenotypic characteristics as $G$. frateurii NBRC $3264^{\mathrm{T}}$ (Table 1). The five isolates of Group 1B were therefore identified as G. frateurii (20-22, 24, 31, 41). They were found in fruits of guava, apple and sugar apple.

\section{(b) Bsp1286I}

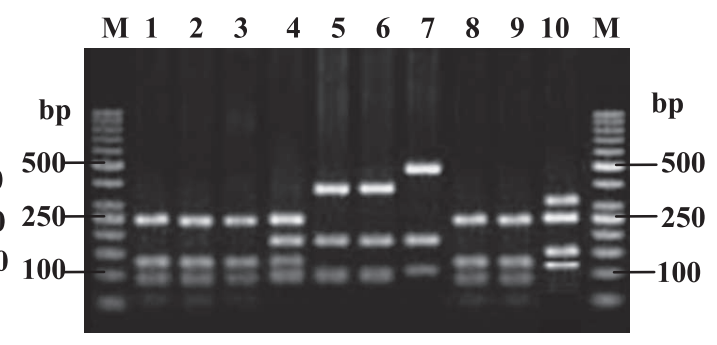

\section{(d) Bst NI}

(c) $\operatorname{Taq} \mathrm{I}$

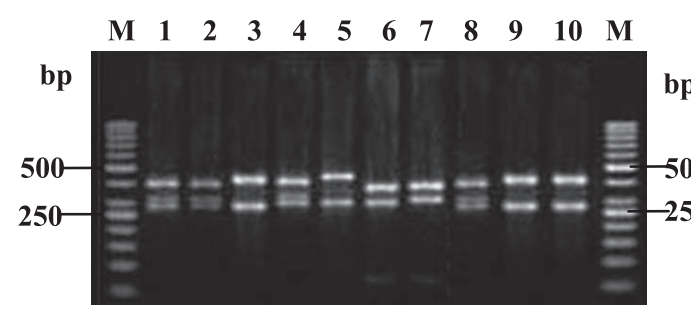

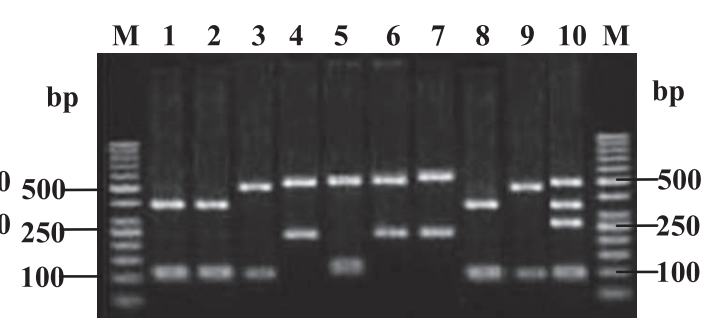

Fig. 4. Restriction of $16 \mathrm{~S}-23 \mathrm{~S}$ rDNA ITS PCR products of Thai isolates assigned to the genus Gluconobacter. The restriction patterns were obtained by digestion of 16S-23S rDNA ITS PCR products with MboII (a), Bsp1286I (b), TaqI (c) and BstNI (d). For the estimation of the resulting restriction fragments, 50-bp DNA markers were used in agarose gel electrophoresis. Strain: 1, G. frateurii NBRC 3264 ${ }^{\mathrm{T}} ; 2$, G. thailandicus BCC $14116^{\mathrm{T}} ; 3$, G. japonicus NBRC $3271^{\mathrm{T}} ; 4$, G. cerinus NBRC $3267^{\mathrm{T}} ; 5$, G. oxydans NBRC $14819^{\mathrm{T}} ; 6$, G. albidus NBRC $3250^{\mathrm{T}} ; 7$, G. kondonii NBRC 3266 ${ }^{\mathrm{T}}$; 8, GB222-1 (Group 1B); 9, GB132-1 (Group 2B); 10, RB88-1 (Group 3B). 
Group 2B was composed of six isolates, GB132-1, F1431, GB125, GB126, GB127, and GB223-2. In a phylogenetic tree based on $16 \mathrm{~S}$ rRNA gene sequences $(1,409 \mathrm{bp})$, the isolates were located within the cluster of G. japonicus (Fig. 2). GB132-1, F143-1, GB125, GB126, GB223-2, and GB127 had $99.9,99.8,99.8,99.9,99.7$, and $99.8 \%$ pair-wise $16 \mathrm{~S}$ rRNA gene sequence similarity with the type strain of $G$. japonicus respectively. All the isolates gave the same restriction patterns as the type strain of G. japonicus (Table 2 and Fig. 4) $(20,24,31,41)$. The isolates produced dihydroxyacetone weakly from glycerol. They produced acids from D-glucose and meso-erythritol (weakly), and in some cases, from L-arabinose, D-galactose, glycerol, D-mannose, D-melibiose, sucrose, and D-xylose. Some isolates produced acids weakly from D-arabinose, dulcitol, D-fructose, lactose, and D-mannitol, but none produced acids from maltose, raffinose, L-rhamnose, L-sorbose, or D-sorbitol. They grew on mesoerythritol, D-arabitol, L-arabitol (weakly), and meso-ribitol. The isolates of Group 2B had a different type of restriction pattern, designated the $d$ type, from the type strains of $G$. frateurii and $G$. thailandicus, all of which gave $c$ type patterns in a 16S-23S rDNA ITS restriction analysis with the endonuclease TaqI. All the isolates were distinguished from $G$. frateurii by the ability to grow on meso-erythritol and produce acid (weakly) from raffinose. They showed almost the same phenotypic characteristics as G. japonicus NBRC $3271^{\mathrm{T}}$ (Table 1) and were identified as G. japonicus $(20,24,31$, 41). The isolates were found in fruits of manila tamarind, plum mango, and sugar apple and in the flower of Canna indica.

Group 3B was composed of one isolate, RB88-1. The calculated pair-wise 16S rRNA gene sequence similarity of RB88-1 for 1,410 bases was 98.3, 98.2, 98.6, 98.6, 97, 97, $97.2,97.2$, and $97.2 \%$, respectively, compared to the type strains of $G$. thailandicus, $G$. cerinus, $G$. japonicus, $G$. frateurii, G. oxydans, G. roseus, G. albidus, G. kondonii, and G. sphaericus (Fig. 2). The isolate was distinguished from the type strains of $G$. oxydans, $G$. cerinus, $G$. albidus, $G$. frateurii, G. japonicus, G. thailandicus, and $G$. kondonii by digestion with MboII, Bsp1286I, TaqI and BstNI (Table 2 and Fig. 4). The isolate produced dihydroxyacetone weakly

Table 3. DNA-DNA relatedness of isolate RB88-1 and the type strains of Gluconobacter species

\begin{tabular}{lcccc}
\hline \multirow{1}{*}{\multicolumn{1}{c}{ Isolate and strain }} & \multicolumn{4}{c}{$\begin{array}{c}\text { \%DNA-DNA relatedness } \\
\text { with labeled strains* }\end{array}$} \\
\cline { 2 - 5 } & 1 & 2 & 3 & 4 \\
\hline RB88-1 & 100 & 6.2 & 8.2 & 7.3 \\
G. thailandicus BCC $14116^{\mathrm{T}}$ & 11.8 & 100 & 52.7 & 64.7 \\
G. cerinus NBRC $3267^{\mathrm{T}}$ & 8.4 & 51.6 & 100 & 43.7 \\
G. frateurii NBRC $3264^{\mathrm{T}}$ & 8.5 & 61.3 & 48.5 & 100 \\
G. japonicus NBRC $3271^{\mathrm{T}}$ & 17.7 & 56 & 52 & 62.4 \\
G. roseus NBRC $3990^{\mathrm{T}}$ & 13.8 & 46.3 & 26.2 & 39.9 \\
G. albidus NBRC $3250^{\mathrm{T}}$ & 15.5 & 38.4 & 36.2 & 30.1 \\
G. kondonii NBRC $3266^{\mathrm{T}}$ & 16.1 & 42.8 & 44.8 & 33.3 \\
G. sphaericus NBRC $12467^{\mathrm{T}}$ & 14.4 & 47.4 & 25.5 & 37.2 \\
G. oxydans NBRC $14819^{\mathrm{T}}$ & 13.1 & 45.9 & 28.2 & 35.8 \\
\hline
\end{tabular}

*Strain: 1, RB88-1; 2, G. thailandicus BCC 14116 ${ }^{\mathrm{T}}$; 3, G. cerinus NBRC $3267^{\mathrm{T}} ;$, G. frateurii NBRC $3264^{\mathrm{T}}$. from glycerol. It grew on mannitol agar and at $37^{\circ} \mathrm{C}$ but not on glutamate agar. 2-Keto-D-gluconate and 5-keto-Dgluconate were produced from D-glucose, but not 2,5-diketoD-gluconate. The isolate produced acids from D-arabinose, L-arabinose, dulcitol, D-fructose, D-glucose, D-melibiose, Dsorbitol, L-sorbose, sucrose and D-xylose, and to a lesser extent, from D-galactose, lactose, D-mannose, D-mannitol and L-rhamnose, but not at all on meso-erythritol, maltose, or raffinose. The isolate grew on meso-ribitol but only weakly on L-arabitol, D-arabitol, and meso-erythritol. It differed from G. frateurii NBRC $3264^{\mathrm{T}}$ and $G$. japonicus NBRC $3271^{\mathrm{T}}$ in its ability to grow and produce acid on mesoerythritol (Table 1). In addition, RB88-1 showed low DNADNA relatedness $(6.2-17.7 \%)$ with the type strains of Gluconobacter (Table 3). From the data obtained, the isolate was considered to be a novel species of the genus Gluconobacter $(20-22,24)$. It was found in the fruit of rambutan.

\section{Isolate assigned to the genus Asaia}

Group 1C was composed of only one isolate, GB23-3, which was distinguished phylogenetically from the type strains of the four Asaia species on the basis of the 16S rRNA gene sequence analysis (1,414 bp) (Fig. 2). The isolate was located in the cluster of the genus Asaia and had 99.2, 99.2, 99.1, 99.0, and 98.7\% pair-wise sequence similarity, respectively, to the type strains of Asaia bogorensis, Asaia siamensis, Asaia krungthepensis, Asaia lannaensis, and Swaminathania salitolerans. The isolate produced acetic acid from ethanol on ethanol/calcium carbonate agar differing from the type strains of Asaia bogorensis, Asaia siamensis and Asaia krungthepensis, but similar to Asaia lannaensis. The isolate grew on glutamate agar and mannitol agar. It produced 2-keto-D-gluconate and 5-keto-D-gluconate from Dglucose, but not 2,5-diketo-D-gluconate. Acid was produced from D-arabinose, L-arabinose, dulcitol, D-fructose, D-glucose, glycerol, D-melibiose, D-sorbitol, L-sorbose, sucrose, and D-xylose, but only weakly from meso-erythritol, D-galactose, lactose, maltose, D-mannose, D-mannitol, raffinose, and L-rhamnose. It grew on meso-ribitol but grew weakly on meso-erythritol, D-arabitol, and L-arabitol. This strain could be differentiated from related Asaia species by the acid it produced from ethanol and maltose (Table 1). In addition, GB23-3 showed low DNA-DNA relatedness (35.0-58.7\%)

Table 4. DNA-DNA relatedness of isolate GB23-3 and the type strains of Asaia, Swaminathania, and Neoasaia species

\begin{tabular}{|c|c|c|c|c|c|}
\hline \multirow{2}{*}{ Isolate and strain } & \multicolumn{5}{|c|}{$\begin{array}{l}\text { \%DNA-DNA relatedness with } \\
\text { labeled strains* }\end{array}$} \\
\hline & 1 & 2 & 3 & 4 & 5 \\
\hline GB23-3 & 100 & 28.3 & 45.5 & 55.7 & 40.6 \\
\hline Asaia bogorensis BCC $12264^{\mathrm{T}}$ & 35 & 100 & 51.6 & 47.5 & 67.9 \\
\hline Asaia krungthepensis BCC $12978^{\mathrm{T}}$ & 47.9 & 56.2 & 100 & 58.4 & 58.3 \\
\hline Asaia siamensis $\mathrm{BCC} 12268^{\mathrm{T}}$ & 52.6 & 59.9 & 51.9 & 100 & 61.6 \\
\hline Asaia lannaensis $\mathrm{BCC} 15733^{\mathrm{T}}$ & 58.7 & 46.3 & 39.7 & 40.2 & 100 \\
\hline S. salitolerans $\mathrm{PA} 51^{\mathrm{T}}$ & 50.3 & 38 & 35.6 & 17.9 & 53.1 \\
\hline N. chiangmaiensis $\mathrm{BCC} 15763^{\mathrm{T}}$ & 26.9 & 14.5 & 10.6 & 10.3 & 17 \\
\hline
\end{tabular}

*Strain: 1, GB23-3; 2, Asaia bogorensis BCC 12264 ${ }^{\mathrm{T}}$; 3, Asaia krungthepensis BCC $12978^{\mathrm{T}}$; 4, Asaia siamensis BCC $12268^{\mathrm{T}}$; 5 , Asaia lannaensis $\mathrm{BCC} 15733^{\mathrm{T}}$. 
with the type strains of Asaia (Table 4). From the data obtained, the isolate was considered to constitute a novel species in the genus Asaia $(11,23,38-40)$.

Seearunruangchai et al. (27) isolated forty acetic acid bacteria from fruits in Thailand. Thirty-one of the isolates, some $77 \%$ of the total were identified as A. pasteurianus. Three isolates (only $8 \%$ ) were identified as $A$. orientalis, and the remaining six isolates (15\%) from sugar cane, palm and coconut juice were identified as Gluconacetobacter liquefaciens.

Kommanee et al. (15) isolated ninety Acetobacter strains from fruits, flowers and other materials collected in Thailand. The isolates were divided into three groups, Group A containing fifty-three isolates identified as A.pasteurianus, Group B containing forty-two isolates identified as $A$. orientalis, and Group $\mathrm{C}$ containing two isolates identified as $A$. lovaniensis. The present study demonstrated similar results, with the Thai isolates mostly identified as two species, $A$. pasteurianus and $A$. orientalis, along with a very small number identified as $A$. lovaniensis.

Huong et al. (9) examined forty-four Thai isolates assigned to the genus Gluconobacter and classified them into seven groups. However, no isolate was identified as $G$. cerinus. The present study gave the same results.

Four species, viz., Asaia bogorensis, Asaia siamensis, Asaia krungthepensis, and Asaia lannaensis are presently described in the genus Asaia (11, 23, 38-40). GB23-3 assigned to the genus Asaia was characterized by the production of acetic acid from ethanol, as found in the type strain of Asaia lannaensis but not in the type strains of Asaia bogorensis, Asaia siamensis and Asaia krungthepensis. The present study demonstrated that the Thai isolate constitutes a new species.

From the results obtained above, the Thai isolates of acetic acid bacteria assigned to the genera Acetobacter, Gluconobacter and Asaia were not successfully identified at the species level by the phenotypic characterization but the $16 \mathrm{~S}$ rRNA gene sequence and 16S-23S rDNA ITS restriction analyses using HpaII, HaeIII, MboII, Bsp1286I, TaqI and $B s t$ NI were useful. In addition, the DNA-DNA relatedness data made clear the taxonomic position of novel species. However, use of the 16S-23S rDNA ITS restriction analysis in the differentiation of Asaia species should be studied further.

In comparison with Indonesian isolates $(16,17)$ and African isolates (3), the Thai isolates of Acetobater species were similar in phenotypic features but somewhat different in isolation sources. For example, the Thai isolates of $A$. tropicalis and $A$ orientalis were obtained respectively from a flower of Spathodea campanulata and fruits of kaffir lime, muskmelon and loog-pang khaomak (sweeted rice starter), however, the type strains of the species were from coconut and a canna flower in Indonesian sources $(16,17)$. In A. ghanensis, the Thai isolates were from tomato and peach in contrast to traditional heap fermentations of Ghanaian cocoa beans (3). It is of interest that $G$. japonicus, which was recently described for Japanese strains (24) was found in Thai isolates but not in Indonesian isolates (37). In the present study, possible new species of Gluconobacter from the fruit of rambutan and Asaia from the flower of Spathodea campanulata were recognized.

\section{Acknowledgements}

This study was supported in part by the Faculty of Pharmaceutical Sciences Research Fund (2008), Chulalongkorn University, Bangkok, Thailand.

\section{References}

1. Asai, T., H. Iizuka, and K. Komagata. 1964. The flagellation and taxonomy of genera Gluconobacter and Acetobacter with reference to the existence of intermediate strains. J. Gen. Appl. Microbiol. 10:95-126

2. Brosius, J., T.J. Dull, D.D. Sleeter, and H.F. Noller. 1981. Gene organization and primary structure of a ribosomal RNA operon from Escherichia coli. J. Mol. Biol. 148:107-127.

3. Cleenwerck, I., N. Camu, K. Engelbeen, T. De Winter, K. Vandemeulebroecke, P. De Vos, and L. De Vuyst. 2007. Acetobacter ghanensis sp. nov., a novel acetic acid bacterium isolated from traditional heap fermentations of Ghanaian cocoa beans. Int. J. Syst. Evol. Microbiol. 57:1647-1652.

4. Ezaki, T., Y. Hashimoto, and E. Yabuuchi. 1989. Fluorometric deoxyribonucleic acid-deoxyribonucleic acid hybridization in microdilution wells as an alternative to membrane filter hybridization in which radioisotopes are used to determine genetic relatedness among bacterial strains. Int. J. Syst. Bacteriol. 39:224-229.

5. Felsenstein, J. 1985. Confidence limits on phylogenies: An approach using the bootstrap. Evolution 39:783-791.

6. Gosselé, J., J. Swings, and J. De Ley. 1980. A rapid, simple and simultaneous detection of 2-keto, 5-keto- and 2,5-diketogluconic acids by thin layer chromatography in culture media of acetic acid bacteria. Zentralbl. Bakteriol. Mikrobiol. Hyg. 1 Abt. Orig. C 1:178181.

7. Greenberg, D.E., S.F. Porcella, F. Stock, A. Wong, P.S. Conville, P.R. Murray, S.M. Holland, and A.M. Zelazny. 2006. Granulibacter bethesdensis gen. nov., sp. nov., a distinctive pathogenic acetic acid bacterium in the family Acetobacteraceae. Int. J. Syst. Evol. Microbiol. 56:2609-2616.

8. Hucker, G.J., and H.J. Conn. 1923. Method of Gram staining. N. Y. State. Agric. Exp. Stn. Tech. Bull. 93:3-37.

9. Huong, V.T.L., T. Malimas, P. Yukphan, W. Potacharoen, S. Tanasupawat, L.T.T. Loan, M. Tanticharoen, and Y. Yamada. 2007. Identification of Thai isolates assigned to the genus Gluconobacter based on 16S-23S rDNA ITS restriction analysis. J. Gen. Appl. Microbiol. 53:133-142.

10. Jojima, Y., Y. Mihara, S. Suzuki, K. Yokozeki, S. Yamanaka, and R. Fudou. 2004. Saccharibacter floricola gen. nov., sp. nov., a novel osmophilic acetic acid bacterium isolated from pollen. Int. J. Syst. Evol. Microbiol.54:2263-2267.

11. Katsura, K., H. Kawasaki, W. Potacharoen, S. Saono, T. Seki, Y. Yamada, T. Uchimura, and K. Komagata. 2001. Asaia siamensis sp. nov., an acetic acid bacterium in the $\alpha$-Proteobacteria. Int. J. Syst. Evol. Microbiol. 51:559-563.

12. Katsura, K., Y. Yamada, T. Uchimura, and K. Komagata. 2002 Gluconobacter asaii Mason and Claus 1989 is a junior subjective synonym of Gluconobacter cerinus Yamada and Akita 1994. Int. J. Syst. Evol. Microbiol. 52:1635-1640.

13. Kersters, K., P. Lisdiyanti, K. Komagata, and J. Swings. 2006. The family Acetobacteraceae: The genera Acetobacter, Acidomonas, Asaia, Gluconacetobacter, Gluconobacter, and Kozakia. p. 163-200. In M. Dworkin, S. Falcow, E. Rosenberg, K.H. Schleifer, and E. Stackebrands (ed.), The Prokaryotes, 3rd ed., vol. 5. Springer, New York, USA.

14. Kimura, M. 1980. A simple method for estimating evolutionary rates of base substitutions through comparative studies of nucleotide sequences. J. Mol. Evol. 16:111-120.

15. Kommanee, J., A. Akaracharanya, S. Tanasupawat, T. Malimas, P. Yukphan., Y. Nakagawa, and Y. Yamada. 2008. Identification of Acetobacter strains isolated in Thailand based on 16S-23S rDNA gene ITS restriction and 16S rRNA gene sequence analyses. Ann. Microbiol. 58:319-324.

16. Lisdiyanti, P., H. Kawasaki, T. Seki, Y. Yamada, T. Uchimura, and 
K. Komagata. 2000. Systematic study of the genus Acetobacter with descriptions of Acetobacter indonesiensis sp. nov., Acetobacter tropicalis sp. nov., Acetobacter orleanensis (Henneberg 1906) comb. nov., Acetobacter lovaniensis (Frateur 1950) comb. nov., and Acetobacter estunensis (Carr 1958) comb. nov. J. Gen. Appl. Microbiol. 46:147-165.

17. Lisdiyanti, P., H. Kawasaki, T. Seki, Y. Yamada, T. Uchimura, and K. Komagata. 2001. Identification of Acetobacter strains isolated from Indonesian sources, and proposals of Acetobacter syzygii sp. nov., Acetobacter cibinongensis sp. nov., and Acetobacter orientalis sp. nov. J. Gen. Appl. Microbiol. 47:119-131.

18. Lisdiyanti, P., H. Kawasaki, Y. Widyastuti, S. Saono, T. Seki, Y. Yamada, T. Uchimura, and K. Komagata. 2002. Kozakia baliensis gen. nov., sp. nov., a novel acetic acid bacterium in the alphaProteobacteria. Int. J. Syst. Evol. Microbiol. 52:813-818.

19. Loganathan, P., and S. Nair. 2004. Swaminathania salitolerans gen. nov., sp. nov., a salt-tolerant, nitrogen-fixing, and phosphatesolubilizing bacterium from wild rice (Porteresia coarctata Tateoka). Int. J. Syst. Evol. Microbiol. 54:1185-1190.

20. Malimas, T., P. Yukphan, M. Takahashi, W. Potacharoen, S. Tanasupawat, Y. Nakagawa, M. Tanticharoen, and Y. Yamada. 2006. Heterogeneity of strains assigned to Gluconobacter frateurii Mason and Claus 1989 based on restriction analysis of 16S-23S rDNA internal transcibed spacer regions. Biosci. Biotech. Biochem. 70:684-690.

21. Malimas, T., P. Yukphan, M. Takahashi, M. Kaneyasu, W. Potacharoen, S. Tanasupawat, Y. Nakagawa, M. Tanticharoen, and Y. Yamada. 2007. Gluconobacter kondonii sp. nov., an acetic acid bacterium in the alpha-Proteobacteria, an acetic acid bacterium in the alpha-Proteobacteria. J. Gen. Appl. Microbiol. 53:301-307.

22. Malimas, T., P. Yukphan, M. Takahashi, and et al. 2008. Gluconobacter roseus (ex Asai 1935) sp. nov., nom. rev., a pink-colored acetic acid bacterium in the Alphapoteobacteria. J. Gen. Appl. Microbiol. 54:119-125.

23. Malimas, T., P. Yukphan, M. Takahashi, M. Kaneyasu, W. Potacharoen, S. Tanasupawat, Y. Nakagawa, M. Tanticharoen, and Y. Yamada. 2008. Asaia lannaensis sp. nov., a new acetic acid bacterium in the Alphaproteobacteria. Biosci. Biotechnol. Biochem. 72:666-671.

24. Malimas, T., P. Yukphan, M. Takahashi, and et al. 2009. Gluconobacter japonicus sp. nov., an acetic acid bacterium in the Alphaproteobacteria. Int. J. Syst. Evol. Microbiol. 59:466-471.

25. Mason, L.M., and G.W. Claus. 1989. Phenotypic characteristic correlated with deoxyribonucleic acid sequence similarity for three species of Gluconobacter: G. oxydans (Henneberg 1897) De ley 1961, G. frateurii sp. nov., and G. asaii sp. nov. Int. J. Syst. Bacteriol. 39:174184

26. Saitou, N., and M. Nei. 1987. The neighbor-joining method: A new method for reconstructing phylogenetic trees. Mol. Biol. Evol. 4:406425 .

27. Seearunruangchai, A., S. Tanasupawat, S. Keeratipibut, C. Thawai, T. Itoh, and Y. Yamada. 2004. Identification of acetic acid bacteria isolated from fruits and related materials collected in Thailand. J. Gen. Appl. Microbiol. 50:47-53.

28. Skerman, V.B.D., V. McGowan, and P.H.A. Sneath. 1980. Approved lists of bacterial names. Int. J. Syst. Bacteriol. 30:225-420.

29. Tamaoka, J., Y. Katayama-Fujimura, and H. Kuraishi. 1983. Analysis of bacterial menaquinone mixtures by high-performance liquid chromatography. J. Appl. Bacteriol. 54:31-36.

30. Tamura, K., J. Dudley, M. Nei, and S. Kumar. 2007. MEGA4: Molecular evolutionary genetics analysis (MEGA) software version 4.0.
Mol. Biol. Evol. 24:1596-1599.

31. Tanasupawat, S., C. Thawai, P. Yukphan, D. Moonmangmee, T. Itoh, O. Adachi, and Y. Yamada. 2004. Gluconobacter thailandicus sp. nov., an acetic acid bacterium in the $\alpha$-Proteobacteria. J. Gen. Appl. Microbiol. 50:159-167.

32. Thompson, J.D., T.J. Gibson, F. Plewniak, F. Jeanmougin, and D.G. Higgins. 1997. The CLUSTAL X windows interface: Flexible strategies for multiple sequence alignment aided by quality analysis tools. Nucleic Acids Res. 25:4876-4882.

33. Urakami, T., J. Tamaoka, J., K. Suzuki, and K. Komagata. 1989. Acidomonas gen. nov., incorporating Acetobacter methanolicus as Acidomonas methanolica comb. nov. Int. J. Syst. Bacteriol. 39:50-55.

34. Verlander, C.P. 1992. Detection of horseradish peroxidase by colorimetry. p. 185-201. In L.J. Kricka (ed.), Nonisotopic DNA Probe Techniques, Academic Press, New York, USA.

35. Yamada, Y., K. Aida, and T. Uemura. 1969. Enzymatic studies on the oxidation of sugar and sugar alcohol. V. Ubiquinone of acetic acid bacteria and its relation to classification of Gluconobacter and Acetobacter, especially of the so-called intermediate strains. J. Gen. Appl. Microbiol. 15:186-196.

36. Yamada, Y., Y. Okada, and K. Kondo. 1976. Isolation and characterization of "polarly flagellated intermediate strains" in acetic acid bacteria. J. Gen. Appl. Microbiol. 22:237-245.

37. Yamada, Y., R. Hosono, P. Lisdyanti, Y. Widyastuti, S. Saono, T. Uchimura, and K. Komagata. 1999. Identification of acetic acid bacteria isolated from Indonesian sources, especially of isolates classified in the genus Gluconobacter. J. Gen. Appl. Microbiol. 45:23-28.

38. Yamada, Y., K. Katsura, H. Kawasaki, Y. Widyastuti, S. Saono, T. Seki, T. Uchimura, and K. Komagata. 2000. Asaia bogorensis gen. nov., sp. nov., an unusual acetic acid bacterium in the $\alpha$-Proteobacteria. Int. J. Syst. Evol. Microbiol. 50:823-829.

39. Yamada, Y., and P. Yukphan. 2008. Genera and species in acetic acid bacteria. Int. J. Food Microbiol. 125:15-24.

40. Yukphan, P., W. Potacharoen, S. Tanasupawat, M. Tanticharoen, and Y. Yamada. 2004. Asaia krungthepensis sp. nov., an acetic acid bacterium in the $\alpha$-Proteobacteria. Int. J. Syst. Evol. Microbiol. 54:313316.

41. Yukphan, P., W. Potacharoen, Y. Nakagawa, M. Tanticharoen, and Y. Yamada. 2004. Identification of strains assigned to the genus Gluconobacter Asai 1935 based on the sequence and the restriction analyses of the $16 \mathrm{~S}-23 \mathrm{~S}$ rDNA internal transcribed spacer regions. J. Gen. Appl. Microbiol. 50:9-15.

42. Yukphan, P., M. Takahashi, W. Potacharoen, S. Tanasupawat, Y. Nakagawa, M. Tanticharoen, and Y. Yamada. 2004. Gluconobacter albidus (ex Kondo and Ameyama 1958) sp. nov., nom. rev., an acetic acid bacterium in the $\alpha$-Proteobacteria. J. Gen. Appl. Microbiol. 50:235-242.

43. Yukphan, P., T. Malimas, W. Potacharoen, S. Tanasupawat, M. Tanticharoen, and Y. Yamada. 2005. Neoasaia chiangmaiensis gen. nov., sp. nov., a novel osmotolerant acetic acid bacterium in the $\alpha$ Proteobacteria. J. Gen. Appl. Microbiol. 51:301-311.

44. Yukphan, P., T. Malimas, M. Takahashi, M. Kaneyasu, W. Potacharoen, S. Tanasupawat, Y. Nakagawa, M. Tanticharoen, and Y. Yamada. 2006. Identification of strains assigned to the genus Asaia Yamada et al. 2000 based on 16S rDNA restriction analysis. J. Gen. Appl. Microbiol. 52:241-247.

45. Yukphan, P., T. Malimas, Y. Muramatsu, and et al. 2008. Tanticharoenia sakaeratensis gen. nov., sp. nov., a new osmotolerant acetic acid bacterium in the $\alpha$-Proteobacteria. Biosci. Biotechnol. Biochem. 72:672-676. 